\title{
MEMAKNAI PERSATUAN DALAM KEHIDUPAN MULTIKULTURAL SEBAGAI PENANGKAL RADIKALISME
}

\begin{abstract}
Darul Lailatul Qomariyah, M. Ag
Guru Madrasah Aliyah Negeri 2 Ponorogo

Abtrak

Indonesia as a country that stands on cultural diversity requires the importance of multiculturalism in nation building. With this multiculturalism, the principle of "unity in diversity" as stated in the basis of the state will be realized. The cultural diversity possessed by the Indonesian people will be an inspiration and potential for national development so that the ideals to realize a just and prosperous of Indonesian society as stated in the opening of the 1945 Constitution can be achieved. Various concepts which are relevant to multiculturalism such as democracy, justice and law, cultural values and ethos, togetherness in equal differences, ethnicity, ethnicity, ethnic culture, religious beliefs, religious expressions, cultural expressions, private and public domains, human rights, community cultural rights, and others. The emergence of the concept of multiculturalism is often associated with religion, namely "religious multiculturalism" which emphasizes the non-separation of religion from the state, does not tolerate the existence of understanding, culture, and people who are atheists (Harahap, 2008). In this context, multiculturalism is seen as an enrichment of the concept of religious harmony that is developed nationally. By embodying the right multicultural concept, it is believed that it can counteract the understanding of radicalism that can threaten the divisions of the Indonesian nation.
\end{abstract}

Keywords: unity, multiculturalism, radicalism

\section{A. PENDAHULUAN}

Multikulturalisme adalah sebuah filosofi - terkadang ditafsirkan sebagai ideologi - yang menghendaki adanya persatuan dari berbagai kelompok kebudayaan dengan hak dan status sosial politik yang sama dalam masyarakat modern. Istilah multikultural juga sering digunakan untuk menggambarkan kesatuan berbagai etnis masyarakat yang berbeda dalam suatu negara.

Istilah multikulturalisme sebenarnya belum lama menjadi objek pembicaraan dalam berbagai kalangan, namun dengan cepat berkembang sebagai objek perdebatan yang menarik untuk dikaji dan didiskusikan. Dikatakan menarik karena memperdebatkan keragaman etnis dan budaya, serta penerimaan kaum imigran di suatu negara, pada awalnya hanya dikenal dengan istilah pluralisme yang mengacu pada keragaman etnis dan budaya dalam suatu daerah atau negara. Baru pada sekitar pertengahan abad ke-20, mulai berkembang istilah multikulturalisme. Istilah ini, setidaknya memiliki tiga unsur, yaitu: budaya, keragaman budaya dan cara khusus untuk mengantisipasi keanekaragaman budaya tersebut. Secara umum, masyarakat 
modern terdiri dari berbagai kelompok manusia yang memiliki status budaya dan politik yang sama. Selanjutnya, demi kesetaraan masa kini, pengakuan adanya pluralisme kultural menjadi suatu tuntutan dari konsep keadilan sosial (Okke KS Zaimar, 2007: 6).

\section{B. Konsep Multikulturalisme}

Multikulturalisme berasal dari dua kata: multi (banyak/beragam) dan cultural (budaya atau kebudayaan), yang secara etimologi berarti keberagaman budaya. Multikulturalisme diartikan sebagai gejala pada seseorang atau suatu masyarakat yang ditandai oleh kebiasaan menggunakan lebih dari satu kebudayaan (KBBI Daring III). Budaya yang mesti dipahami, adalah bukan budaya dalam arti sempit, melainkan mesti dipahami sebagai semua dialektika manusia terhadap kehidupannya. Dialektika ini akan melahirkan banyak wajah, seperti sejarah, pemikiran, budaya verbal, bahasa dan lain-lain.

Konsep tentang mutikulturalisme, sebagaimana konsep ilmu-ilmu sosial dan kemanusiaan yang tidak bebas nilai (value free), tidak luput dari pengayaan maupun penyesuaian ketika dikaji untuk diterapkan. Demikian pula ketika konsep ini masuk ke Indonesia, yang dikenal dengan sosok keberagamannya. Munculnya konsep multikulturalisme seringkali dikaitkan dengan agama, yakni "multikulturalisme religius" yang menekankan tidak terpisahnya agama dari negara, tidak mentolerir adanya paham, budaya, dan orang-orang yang atheis (Harahap, 2011). Dalam konteks ini, multukulturalisme dipandang sebagai pengayaan terhadap konsep kerukunan umat beragama yang dikembangkan secara nasional.

Misrawi mengemukakan pentingnya multikulturalisme sebagai alternatif membangun kesadaran hidup kebersamaan secara damai dalam konteks kebangsaan dan kemanusiaan universal. Dalam hal ini, multikulturalisme meniscayakan koeksistensi,keterbukaan, pengenalan, pemahaman, pengakuan, dan penghargaan. Lebih jauh, Parsudi Suparlan memberikan penekanan, bahwa multikulturalisme adalah ideologi yang mengakui dan mengagungkan perbedaan dalam kesederajatan, baik secara individu maupun kebudayaan. Yang menarik disini adalah penggunaan kata ideologi sebagai penggambaran bahwa betapa mendesaknya kehidupan yang menghormati perbedaan, dan memandang setiap keberagaman sebagai suatu kewajaran serta sederajat. 
Multikulturalisme adalah sebuah ideologi dan sebuah alat untuk meningkatkan derajat manusia dan kemanusiaannya. Untuk dapat memahami multikulturalisme diperlukan landasan pengetahuan yang berupa bangunan konsep-konsep yang relevan dan mendukung keberadaan serta berfungsinya multikulturalisme dalam kehidupan manusia. Bangunan konsep-konsep ini harus dikomunikasikan di antara para ahli yang mempunyai perhatian ilmiah yang sama tentang multikulturalisme sehingga terdapat kesamaan pemahaman dan saling mendukung dalam memperjuangkan ideologi ini. Berbagai konsep yang relevan dengan multikulturalisme antara lain adalah, demokrasi, keadilan dan hukum, nilai-nilai budaya dan etos, kebersamaan dalam perbedaan yang sederajat, sukubangsa, kesukubangsaan, kebudayaan sukubangsa, keyakinan keagamaan, ungkapanungkapan budaya, domain privat dan publik, HAM, hak budaya komuniti, dan konsep-konsep lainnya yang relevan.

Multikulturalisme sebagaimana dijelaskan di atas mempunyai peran yang besar dalam pembangunan bangsa. Indonesia sebagai suatu negara yang berdiri di atas keanekaragaman kebudayaan meniscayakan pentingnya multikulturalisme dalam pembangunan bangsa. Dengan multikulturalisme ini maka prinsip "bhineka tunggal ika" seperti yang tercantum dalam dasar negara akan menjadi terwujud. Keanekaragaman budaya yang dimiliki oleh bangsa Indonesia akan menjadi inspirasi dan potensi bagi pembangunan bangsa sehingga cita-cita untuk mewujudkan masyarakat Indonesia yang adil, makmur, dan sejahtera sebagaimana yang tercantum dalam pembukaan Undang-undang Dasar 1945 dapat tercapai.

Adalah Samuel P. Huntington (1997) yang "meramalkan" bahwa sebenarnya konflik antar peradaban di masa depan tidak lagi disebabkan oleh faktor-faktor ekonomi, politik dan ideologi, tetapi justru dipicu oleh masalah masalah suku, agama, ras dan antargolongan (SARA). Konflik tersebut menjadi gejala terkuat yang menandai runtuhnya polarisasi ideologi dunia kedalam komunisme dan kapitalisme. Bersamaan dengan runtuhnya struktur politik negara-negara Eropa Timur. Ramalan ini sebenarnya telah didukung oleh peristiwa sejarah yang terjadi pada era 1980-an yaitu terjadinya perang etnik di kawasan Balkan, di Yugoslavia., pasca pemerintahan Josep Broz Tito: Keragaman, yang disatu sisi merupakan kekayaan dan kekuatan, berbalik menjadi sumber perpecahan ketika leadership yang mengikatnya lengser. 
Ramalan Huntington tersebut diperkuat dengan alasannya mengapa di masa depan mendatang akan terjadi benturan antarperadaban. Antara lain adalah: Pertama, perbedaan antara peradaban tidak hanya riil, tetapi juga mendasar. Kedua, Dunia sekarang semakin menyempiti interaksi antara orang yang berbeda peradaban semakin meningkat. Ketiga, proses modernisasi ekonomi dan sosial dunia membuat orang ataumasyarakat tercerabut dari identitas lokal mereka yang sudah berakar dalam, diasmping memperlemah negara-negara sebagi sumber identitas mereka. Keempat, timbulnya kesadaran peradaban dimungkinkan karena peran ganda Barat. Disatu sisi barat berada di punjak kekuatan. Di sisi lain mungkin ini akibat dari posisi Barat tersebut, kembalinya fenomena asal , sedang berlangsung diantara peradabanperadaban Non-Barat. Kelima, karakteristik dan perbedaan budaya kurang bisa menyatu dan karena itu kurang bisa berkompromi dibanding karakteristik dan perbedaan politik dan ekonomi. Dan, keenam regionalisme ekonomi semakin meningkat.

Akan tetapi asumsi tersebut tidak mutlak menjadi sebab utama terjadinya sebuah perpecahan. Misalnya, setelah berakhirnya Perang Dingin, kecenderungan yang terjadi bukanlah pengelompokan masyarakat ke dalam entitas tertinggi, yaitu pengelompokan peradaban, tetapi perpecahan menuju entitas yang lebih kecil lagi, yaitu berdasarkan suku dan etnisitas. Hal ini jelas sekali terlihat pada disintegrasi Uni Soviet yang secara ironis justru disatukan oleh dasar budaya dan peradaban yang sama. Dan lain lagi, persoalan perpecahan antara Jerman Barat dan Jerman Timur yang kembali bersatu karena persamaan suku dan kebudayaan. Dan "multikulturalisme justru menjadi sebuah pemersatu yang kokoh.

Hal tersebut juga terjadi di Indonesia. Ketika Indonesia lahir sebagai negara nasional, Indonesia bukanlah entitas yang baru. Ia merupakan kelanjutan sejarah dari masyarakat yang disebut Hindia Belanda. Masyarakat di bawah penjajah Barat ini merupakan masyarakat majemuk, masyarakat yang terpisah-pisah ber-dasarkan kelas sosial, suku, agama, ras, dan an-tar golongan. Antara penguasa dan rakyat terpisah secara garis rasial. Selain itu ada pemisahan suku bangsa terkait dengan ekonomi, pendidikan, dan hubungan-hubungan sosial. Setelah Indonesia merdeka situasi masyarakat majemuk terus berlangsung.

Berakhirnya Orde Baru telah membuka kotak pandora buruknya hubungan antar etnik dan antar agama. Akibatnya banyak terjadi konflik-konflik yang 
berdasarkan perbedaan etnik dan agama. Hal itu semakin meruncing ketika kepentingan-kepentingan politik masuk. Proses reformasi politik melahirkan kesadaran baru tentang hubungan antar etnik dan agama. Titik awal peru-bahan ini ketika Presiden Abdurahman Wahid membuka sekat-sekat hubungan multikultural yang menghormati perbedaan dalam orientasi budaya di kalangan etnik yang ada. Sejak itu konsep multikulturalisme mengalami proses sosialisi dalam masyarakat Indonesia (Paramita: Historical Studies Journal (2013) 23(2)).

\section{Multikulturalisme Menurut Al Qur'an}

Kita perlu kembali merenungkan berbagai ajaran yang telah disampaikan Allah melalui para Rasul-Nya, yang terdapat dalam kitab Suci Al Qur'an. Kita hendaknya mampu mengoptimalkan peran agama sebagai faktor integrasi dan pemersatu. $\mathrm{Al}$ Qur'an, misalnya, memuat banyak sekali ayat yang bisa dijadikan asas untuk menghormati dan melakukan rekonsiliasi di antara sesama manusia. Dalam tulisan ini dapat dikemukakan contoh sebagai berikut: Pertama, Al Qur'an menyatakan bahwa dulu manusia adalah umat yang satu. (setelah timbul perselisihan) maka Allah mengutus para Nabi, sebagai pemberi kabar gembira dan pemberi peringatan. Dan Allah menurunkan bersama mereka kitab yang benar, untuk memberikan keputusan di antara manusia tentang perkara yang mereka perselisihkan.

"Tidak berselisih tentang kitab itu melainkan orang yang telah didatangkan kepada mereka kitab, yaitu setelah datang kepada mereka keterangan-keterangan yang nyata, karena dengki antara mereka sendiri. Maka Allah memberi petunjuk orang-orang yang beriman kepada kebenaran tentang hal yang mereka perselisihkan itu dengan kehendakNya. Dan Allah selalu memberi petunjuk kepada orang yang Dia kehendaki kepada jalan yang lurus," (QS Al Baqarah: 213).

Dengan ayat ini, Al Qur'an menegaskan konsep kemanusiaaan universal Islam yang mengajarkan bahwa umat manusia pada mulamya adalah satu. Perselisihan terjadi disebabkan oleh timbulnya berbagai vested interest masing-masing kelompok manusia. Yang masing-masing mereka mengadakan penafsiran yang berbeda tentang suatu hakekat kebenaran menurut vested interest nya. Kedua, meskipun asal mereka adalah satu, pola hidupnya menganut hukum tentang kemajemukan, antara lain karena Allah menetapkan jalan dan pedoman hidup yang berbeda-beda untuk berbagai golongan manusia. Perbedaan itu seharusnya tidak menjadi sebab 
perselisiahan dan permusuhan, melainkan pangkal tolak bagi perlombaan untuk melakukan berbagai kebaikan. Al Qur'an menyebutkan:

“.... Untuk tiap-tiap manusia diantara kamu, Kami berikan jalan dan pedoman hidup. Sekiranya Allah menghendaki, niscaya kamu dijadikannya satu umat saja. Tetapi Allah hendak menguji kamu terhadap pemberianNya kepadamu, maka berlomba-lombalah berbuat kebaikan. Hanya kepada Allah-lah kembali kamu semua, lalu diberitahukan-Nya kepadamu apa yang telah kamu perselisihkan itu". Dari kedua ayat diatas dapat disimpulkan bahwa betapapun perbuatan yang terjadi pada manusia di bumi ini, namun hakekat kemanusiaan akan tetap dan tidak akan berubah. Yaitu fitrahnya yang hanif, sebagai wujud perjanjian primordial (azali) antara Tuhan dan Manusia sendiri. Responsi atau timbal balik manusia kepada ajaran tentang kemanusiaan universal adalah kelanjutan dan eksisitensialisme dari perjanjian primordial itu dalam hidup di dunia ini.

Selain itu, kita juga harus membutuhkan sebuah artikulasi atau penjabaran suatu visi dari dalam yang baru tentang manusia. Sekarang menjadi suatu keharusan bahwa semua agama harus mengambil bagian. Sekurang-kurangnya untuk sebagian dari sebuah visi dari dalam, sebuah konsep manusia mengenai dirinya sendiri, sesama, bahkan dengan orang yang menyatakan dirinya tidak beragama. Dalam pencarian itu mungkin sangat penting bagi umat beragama untuk melihat kepada pribadi-pribadi terkemuka yang dimilikinya dan peninggalan kolektifnya di massa lampau.

\section{Implementasi Multikulturalisme sebagai penangkal Radikalisme di Indonesia}

Kesadaran multikultur sebenarnya sudah muncul sejak Negara Republik Indonesia terbentuk. Pada masa Orde Baru, kesadaran tersebut dipendam atas nama kesatuan dan persatuan. Paham monokulturalisme kemudian ditekankan. Akibatnya sampai saat ini, wawasan multikulturalisme bangsa Indonesia masih sangat rendah. Ada juga pemahaman yang memandang multikultur sebagai eksklusivitas. Multikultur justru disalahartikan yang mempertegas batas identitas antar individu. Bahkan ada yang juga mempersoalkan masalah asli atau tidak asli.

Multikultur baru muncul pada tahun 1980-an yang awalnya mengkritik penerapan demokrasi. Pada penerapannya, demokrasi ternyata hanya berlaku pada kelompok tertentu. Wacana demokrasi itu ternyata bertentangan dengan perbedaanperbedaan dalam masyarakat. Cita-cita reformasi untuk membangun Indonesia Baru 
harus dilakukan dengan cara membangun dari hasil perombakan terhadap keseluruhan tatanan kehidupan yang dibangun oleh Orde Baru.

Inti dari cita-cita tersebut adalah sebuah masyarakat sipil demokratis, adanya dan ditegakkannya hukum untuk supremasi keadilan, pemerintahan yang bersih dari KKN, terwujudnya keteraturan sosial dan rasa aman dalam masyarakat yang menjamin kelancaran produktivitas warga masyarakat, dan kehidupan ekonomi yang mensejahterakan rakyat Indonesia. Bangunan Indonesia Baru dari hasil reformasi atau perombakan tatanan kehidupan Orde Baru adalah sebuah "masyarakat multikultural Indonesia" dari puing-puing tatanan kehidupan Orde Baru yang bercorak "masyarakat" (plural society) sehingga corak masyarakat Indonesia yang Bhinneka Tunggal Ika bukan lagi keanekaragaman suku bangsa dan kebudayaannya tetapi keanekaragaman kebudayaan yang ada dalam masyarakat Indonesia.

Acuan utama bagi terwujudnya masyarakat Indonesia yang multikultural adalah multikulturalisme, yaitu sebuah ideologi yang mengakui dan mengagungkan perbedaan dalam kesederajatan baik secara individual maupun secara kebudayaan. Dalam model multikulturalisme ini, sebuah masyarakat dilihat sebagai mempunyai sebuah kebudayaan yang berlaku umum dalam masyarakat tersebut yang coraknya seperti sebuah mozaik. Di dalam mozaik tercakup semua kebudayaan dari masyarakat-masyarakat yang lebih kecil yang membentuk terwujudnya masyarakat yang lebih besar, yang mempunyai kebudayaan yang seperti sebuah mozaik tersebut. Hal yang harus kita waspadai adalah munculnya perpecahan etnis, budaya dan suku di dalam tubuh bangsa kita sendiri.

Bangsa Indonesia yang kita ketahui bersama memiliki bermacam-macam kebudayaan yang dibawa oleh banyak suku, adat-istiadat yang tersebar di seluruh Nusantara. Begitu kayanya bangsa kita dengan suku, adat-istiadat, budaya, bahasa, dan khasanah yang lain ini, apakah benar-benar menjadi sebuah kekuatan bangsa ataukah justru berbalik menjadi faktor pemicu timbulnya disintegrasi bangsa. Seperti apa yang dikemukakan Lestari, G. (2015) bahwa multikulturalisme merupakan given dari Tuhan, namun Bhineka Tunggal Ika merupakan titipan dari nenek moyang kita yang harus di jaga dan dilestarikan.

Hal ini disadari betul oleh para founding father kita, sehingga mereka merumuskan konsep multikulturalisme ini dengan semboyan "Bhineka Tunggal Ika". Sebuah konsep yang mengandung makna yang luar biasa. Baik makna secara 
eksplisit maupun implisit. Secara eksplisit, semboyan ini mampu mengangkat dan menunjukkan akan keanekaragaman bangsa kita. Bangsa yang multikultural dan beragam, akan tetapi bersatu dalam kesatuan yang kokoh. Selain itu, secara implisit "Bhineka Tunggal Ika” juga mampu memberikan semacam dorongan moral dan spiritual kepada bangsa indonesia, khusunya pada masa-masa pasca kemerdekaan untuk senantiasa bersatu melawan ketidakadilan para penjajah. Walaupun berasal dari suku, agama dan bahasa yang berbeda.

Kemudian sebuah ideologi yang diharapkan mampu menjadi jalan tengah sekaligus jembatan yang menjembatani terjadinya perbedaan dalam negara Indonesia. Yaitu Pancasila, yang seharusnya mampu mengakomodasi seluruh kepentingan kelompok sosial yang multikultural, multietnis, dan agama ini. Termasuk dalam hal ini Pancasila haruslah terbuka. Harus memberikan ruang terhadap berkembangannya ideologi sosial politik yang pluralistik. Pancasila adalah ideologi terbuka dan tidak boleh mereduksi pluralitas ideologi sosial-politik, etnis dan budaya. Melalui Pancasila seharusnya bisa ditemukan sesuatu sintesis harmonis antara pluralitas agama, multikultural, kemajemukan etnis budaya, serta ideologi sosial politik, agar terhindar dari segala bentuk konflik yang hanya akan menjatuhkan martabat kemanusiaan itu.

Mengaitkan dengan maraknya radikalisme yang terjadi di Indonesia, penting bagi masyarakat Indonesia untuk bersama-sama bahu membahu dengan mengedepankan persatuan untuk menangkal perpecahan yang sangat dimungkinkan terjadi.

Jatuhnya Soeharto pada tahun 1998 juga diikuti oleh munculnya beberapa kelompok yang mencabut ideologi dan nilai mereka dengan ideologi gerakan politik Islam di Timur Tengah. Banyak penulis bahkan menghubungkan fenomena ini dengan terorisme. Dari sudut pandang itu, mereka mencoba menghadapi terorisme dengan cara meradikalisasi orang dan mempromosikan pemberdayaan masyarakat moderat (Umar, A.R.M.,2010). Tetapi sudut pandang ini dikemukakan oleh beberapa penulis yang berpikir bahwa terorisme berbeda dari radikalisme. Ini adalah masalah struktural - kemiskinan, penindasan, otoriterisme politik - yang menyiratkan kekerasan dan teror. Ini membawa kita pada pertanyaan: Apa yang menyebabkan radikalisme? 
Dalam KBBI disebutkan radikalisme adalah paham atau aliran yang radikal dalam politik; paham atau aliran yang menginginkan perubahan atau pembaharuan sosial dan politik dengan cara kekerasan atau drastis; sikap ekstrem dalam aliran politik. Mengutip dari Wahid Foundation dalam postingan Akar Sejarah Gerakan Radikalisme di Indonesia, Gerakan radikalisme ini awalnya muncul sebagai bentuk perlawanan terhadap komunisme di Indonesia.

Selain itu, perlawanan mereka terhadap penerapan Pancasila sebagai asas Tunggal dalam politik. Bagi Kaum radikalis agama sistem demokrasi pancasila itu dianggap haram hukumnya dan pemerintah di dalamnya adalah kafir taghut (istilah bahasa arab merujuk pada "setan"), begitu pula masyarakat sipil yang bukan termasuk golongan mereka. Oleh sebab itu bersama kelompoknya, kaum ini menggaungkan formalisasi syariah sebagai solusi dalam kehidupan bernegara.

Dalam konstelasi politik di Indonesia, masalah radikalisme Islam telah makin membesar karena pendukungnya juga semakin meningkat. Akan tetapi, gerakangerakan radikal ini kadang berbeda pandangan serta tujuan, sehingga tidak memiliki pola yang seragam. Ada yang sekedar memperjuangkan implementasi syariat Islam tanpa keharusan mendirikan "negara Islam", namun ada pula yang memperjuangkan berdirinya "negara Islam Indonesia", disamping itu pula da yang memperjuangkan berdirinya "khilafah Islamiyah".

Pola organisasinya juga beragam, mulai dari gerakan moral ideology seperti Majelis Mujahidin Indonesai (MMI), Hizbut Tahrir Indonesia serta yang mengarah pada gaya militer seperti Laskar Jihad, Front Pembela Islam, dan Front Pemuda Islam Surakarta. Meskipun demikian, ada perbedaan dikalangan mereka, ada yang kecenderungan umum dari masyarakat untuk mengaitkan gerakan-gerakan ini dengan gerakan radikalisme Islam di luar negeri.

Radikalisme yang berujung pada terorisme menjadi masalah penting bagi umat Islam Indonesia dewasa ini. Dua isu itu telah menyebabkan Islam dicap sebagai agama teror dan umat Islam dianggap menyukai jalan kekerasan suci untuk menyebarkan agamanya. Sekalipun anggapan itu mudah dimentahkan, namun fakta bahwa pelaku teror di Indonesia adalah seorang Muslim garis keras sangat membebani psikologi umat Islam secara keseluruhan. Berbagai aksi radikalisme terhadap generasi muda kembali menjadi perhatian serius oleh banyak kalangan di 
tanah air. Bahkan, serangkaian aksi para pelaku dan simpatisan pendukung, baik aktif maupun pasif, banyak berasal dari berbagai kalangan.

Oleh sebab itu perlu adanya upaya dalam rangka menangkal gerakan radikalisme di Indonesia. Gerakan radikalisme di Indonesia dapat merugikan ketatanegaraan NKRI dan juga tidak sesuai dengan Pancasila. Radikalisme dapat menjadikan negera dipandang rendah oleh bangsa lain sehingga ekonomi negara memburuk, sehingga Pemerintahan Indonesia harus berupaya memulihkan hal tersebut yang tentu merugikan ketatanegaraan. Selain itu radikalisme bertentangan dengan pancasila sila pertama. Tidak ada satupun agama yang di Indonesia yang mengajarkan radikalisme untuk mencapai tujuan dari suatu umat beragama.

Oleh karenanya pondasi kehidupan multicultural yang telah dijalankan selama beberapa abad dapat menjadi perisai kuat bagi bangsa Indonesia untuk dapat menangkal semakin menyebarnya radikalisme, ditopang dengan beberapa hal yang harus kita lakukan: pertama, meningkatkan pemahaman tentang multikulturalisme Indonesia. Perlu dilakukan penumbuhan rasa saling memiliki aset-aset nasional yang berasal dari nilai-nilai adiluhung bangsa Indonesia, khususnya dari suku-suku bangsa, sehingga mendorong terbentuknya shared property dan shared entitlement.

Artinya upaya membuat seseorang dari kawasan Barat Indonesia dapat menghargai, menikmati dan merasakan sebagai milik sendiri berbagai unsur kebudayaan yang terdapat di kawasan Timur Indonesia, dan demikian pula sebaliknya. Kedua, setiap program pembangunan hendaknya mengemban misi menciptakan dan menyeimbangkan mutualisme sebagai wujud doktrin kebersamaan dalam asas kekeluargaan (mutualism and brotherhood) dalam kehidupan berbangsa dan bernegara. Dengan demikian strategi dan kebijakan pembangunan, khususnya strategi dan kebijakan budaya, harus bertolak dan berorientasi pada upaya memperkokoh persatuan Indonesia melalui upaya menumbuhkan mutualisme antar komponen bangsa dan di tingkat grass-roots.

Oleh karena itu, walaupun masyarakat multikultural harus dihargai potensi dan haknya untuk mengembangkan diri sebagai pendukung kebudayaannya di atas tanah kelahiran leluhurnya, namun pada saat yang sama, mereka juga harus tetap diberi ruang dan kesempatan untuk mampu melihat dirinya, serta dilihat oleh masyarakat lainnya yang sama-sama merupakan warga negara Indonesia. Dengan demikian, membangun dirinya, membangun tanah leluhurnya, berarti juga membangun bangsa 
dan tanah air tanpa merasakannya sebagai beban, namun karena ikatan kebersamaan dan saling bekerjasama antara sesama warga Negara dan bangsa Indonesia.

\section{Daftar Pustaka}

Lestari, G. (2015). Bhinnekha Tunggal Ika: Khasanah Multikultural. Jurnal Pendidikan Pancasila Dan Kewarganegaraan, I(Februari), 31-37.

Misrawi, Z. (1970). Kesadaran multikultural dan deradikalisasi pendidikan Islam: pengalaman Bhinneka Tunggal Ika dan Qabul al-Akhar.Jurnal Pendidikan Islam, 2(1), 197. https://doi.org/10.14421/jpi.2013.21.197-215

Mubit R, 2016, Peran Agama dalam Multikulturalisme Masyarakat Indonesia, Epistemé: Jurnal Pengembangan Ilmu Keislaman, vol. 11, issue 1, Published by IAIN Tulungagung

Okke KS Zaimar, Joesana Tjahjani, 2007, Multikulturalisme di Eropa, Jurnal Kajian Wilayah Eropa, Vol. III, No.3, 2007, Jakarta: Program Studi Kajian Wilayah Eropa Program PascaSarjana UI.

Paramita , 2013, INDONESIA: FROM PLURALISM TO MULTICULTURALISM., Historical Studies Journal, 23(2). https://doi.org/10.15294/paramita.v23i2.2665

Parsudi Suparlan, 2014, Menuju Masyarakat Indonesia yang Multikultural, jurnal Antropologi Indonesia, dipublikasikan secara online dalam journal.ui,ac,id., Jakarta :Universitas Indonesia

Samuel P. Huntington, (2002) [1997]. "Chapter 9: The Global Politics of Civilizations". The Clash of Civilizations and the Remaking of World Order (The Free Press ed.). London: Simon \$ Schuster.

Syahrin Harahap, 2011, Teologi Kerukunan, Jakarta: Prenada

Pranala (link): https://kbbi.web.id/multikulturalisme

Umar, A. R. M. (2010). Melacak Akar Radikalisme Islam di Indonesia. Jurnal Ilmu Sosial Dan Ilmu Politik, 14(2), 169-186. https://doi.org/10.1158/1541-7786.MCR-07$\underline{0324}$

http://wahidfoundation.org/index.php/news/detail/Akar-Sejarah-Gerakan$\underline{\text { Radikalisme-di-Indonesia }}$ 